IJ§ER

ISSN: 2149-5939
International Journal of Social Sciences and Education Research

Online, https://dergipark.org.tr/tr/pub/ijsser

Volume: 7(2), 2021

\title{
General perceptions and information sources of people in Turkey in the process of the Covid-19 outbreak
}

\author{
Zakir Avşara, Emrah Ayaşlığlu ${ }^{\mathrm{b}}$, Ömer Faruk Zararsız ${ }^{\mathrm{c}}$ and Can Ozan Tuncer ${ }^{\mathrm{d}}$ \\ ${ }^{a}$ Prof. Dr., Ankara Haci Bayram Veli University, zakir.avsar@hbv.edu.tr ORCID: https://orcid.org/0000-0002-1427-127X \\ ${ }^{b}$ Dr., Ankara Haci Bayram Veli University, emra.ayaslioglu@hbv.edu.tr ORCID: https://orcid.org/0000-0002-9245-7424 \\ ${ }^{c}$ Research Asst., Ankara Haci Bayram Veli University, omer.zararsiz@hbv.edu.tr ORCID: https://orcid.org/0000-0002-0485-7576 \\ ${ }^{d}$ Dr., Yüzüncü Yll University, canozantuncer@gmail.com ORCID: https://orcid.org/0000-0001-9471-4917
}

\begin{tabular}{|c|c|}
\hline Article Info & Abstract \\
\hline Research Article & $\begin{array}{l}\text { This study is an attempt to define and explain the main information sources people applied } \\
\text { to access more information during the Covid-19 pandemic process. Based on the findings of }\end{array}$ \\
\hline Received:10 December 2020 & the field study, the study also aims to reveal the general perceptions of Turkish people to- \\
\hline Revised: 16 March 2021 & wards the outbreak. According to the findings of the survey, conducted on 6021 people over \\
\hline Accepted: 31 March 2021 & $\begin{array}{l}18 \text { years old in } 26 \text { provinces in Turkey, people living in these provinces rely on information } \\
\text { provided by the official authorities mostly and their perception towards the outbreak }\end{array}$ \\
\hline Keywords: & changed significantly both by the perceived proximity of the Covid-19 threat and flow of \\
\hline The Covid-19, & reliable information. \\
\hline Outbreak Perception, & \\
\hline The Covid-19 Strategies, & \\
\hline Turkish Media and Covid-19 & \\
\hline
\end{tabular}

\section{Introduction}

Events, developments or crises that have the power to form a global agenda suddenly change the course of life and cause blurring of all other agendas. In a way, this resembles the sudden emergence of the really important issues on the stage of life in the face of the insignificance of everyday subjects. Events such as terrorist attacks, natural disasters and accidents that generally resonate on a global scale are examples of such important events that wipe the daily agendas and become the main agenda in all its reality. The Covid-19, which was seen in Wuhan City of China's Hubei Province in December 2019 and attracted attention with its effects such as infectiousness and deadliness, occupied the global agendas at once and has become the main global agenda, pushing our daily and ordinary agendas to the background. Following the declaration of the World Health Organization (WHO) as "Pandemic" on 11 March 2020, it has swept all the daily agendas, ordinary threats and important issues "behind the scene" as "the most real agenda" on a global scale. As such, the Covid-19's strong and real "global agenda" feature should be noted. In the fight against the Covid-19 outbreak that started in China, states all over the world took similar precautions in the light of the experiences of China. In this context, Turkey has taken some measures in order to minimize the dangerous effects of the pandemic, which threatens public health. This study contributes to the literature with the field research conducted since the first periods of the pandemic in terms of determining public policies and revealing the perception of the society.

\section{Literature}

\subsection{Brief chronology of the Covid-19 process in Turkey}

Caused by the SARS-CoV-2 virus, the Covid-19 (or 'coronavirus disease', as a widely known and used name by the public in Turkey) reached Turkey later than expected despite its geographic position, which was in part,

* This research has ethics committee approval from Ankara Haci Bayram Veli University with 24.03.2021 date and E11054618-302.08.01-16557 number.

To cite this article: Avşar, Z., Ayaşlığlu, E., Zararsız, Ö.F. \& Tuncer, C.O. (2021). General perceptions and information sources of people in Turkey in the process of the Covid-19 outbreak. International Journal of Social Sciences and Education Research, 7 (2), 129-140. DOI: https://doi.org/10.24289/ijsser.838429

Copyright (C) 2021 by IJSSER

ISSN: 2149-5939 
because of the strict measures implemented in an early stage. Despite stringent measures against SARS-CoV-2 virus taken by the government, first case was seen on March 10, 2020 in Turkey (Euronews, 2020). The first death due to the Covid-19 in Turkey was recorded on March 15, 2020 (Trthaber, 2020a). While the names of the provinces in which the first cases were seen was not publicly announced, Turkish Minister of Health, Fahrettin Koca stated on April 1, 2020 that the virus spread throughout the country (Ntv, 2020a). As of 25 June 2020, the total case was recorded as 193.115, while total death was recorded as 5046 and the total number of recovered patients was 165.706 (Ministry of Health, 2020).

\subsection{Measures and constraints by the government}

Before the emergency was declared by the WHO; the Coronavirus Scientific Board was established within the Ministry of Health on January 10, 2020. The primary mission of the board, which was composed of the leading scientists and academicians of universities, was to closely monitor the developments related to the outbreak (Yener, 2020). The establishment and actions of the Scientific Board in an early period can be considered as an indication that Turkey adopted a scientific perspective for the management of the pandemic. Thermal cameras were installed at the airports on January 24, 2020 and especially passengers from China started to be scanned (Taşkıran, 2020a). Then, passengers from countries where the number of cases increased were included in the screening and everyone who showed symptoms started to be quarantined (Taşkıran, 2020b).

As of February 3, 2020, all flights to China (Deutsche Welle, 2020) and then to other countries where the outbreak occurred gradually ceased (Haberturk, 2020). On March 12 following a meeting chaired by the President, the decision that all sports events must be played without spectators was declared. A special permit condition for public officials who are going abroad was also implemented and declared to the public Presidential Spokesman Ibrahim Kalin (CNN Turk, 2020). Turkey was one of the first countries to implement such measures in an early period, even earlier than many European Union countries.

After their visit to Umrah on March 15, returning Turkish citizens were quarantined in student dormitories across the country (Sputnik, 2020a). Thus, the first quarantine was applied to a group of people, rather than to an individual. On March 19, 2020, the Presidency of Religious Affairs banned the prayers to be performed with the congregation, and decided to keep mosques closed on crowded days such as Friday prayers and holy nights (T24, 2020). On March 21, 2020, curfew was imposed for citizens who are over 65 years old and who had chronic diseases. In addition, it was decided that restaurants and patisseries would only serve in the form of takeaway (Hürriyet, 2020; NTV, 2020b). On April 3, 2020, the President announced that the scope of the curfew above the age of 65 was extended and those born after January 1, 2000 were included in the scope of the ban (Karadağ, 2020).

On March 25, 2020, Turkish Minister of Health and Minister of National Education held a joint meeting, after which they announced that the schools were on vacation until April 30, 2020 (Sözcü, 2020). After school holidays, distance education was initiated through "EBA TV", which is an online education platform developed and maintained by Turkish Radio and Television Corporation (TRT). On March 26, The President of Council of Higher Education (YÖK), announced that higher education in universities would be carried out using distance learning applications in 2020 Spring (Sputnik, 2020b). On March 30, 2020, President of Turkey launched a solidarity campaign. The campaign was mainly based on calling all citizens to donate. It was announced that the amount to be collected by the donation method would be used to meet the needs of people whose cash needs increased due to the pandemic (Sputnik, 2020c). On April 10, 2020, a general curfew was announced, covering April 11-12 (Ministry of Interior, 2020a) and April 23-24-25-26, 2020 (Ministry of Interior, 2020b) in 30 metropolitan cities and Zonguldak province.

\subsection{Communication strategy of the government}

The Turkish Government's primary goal was to prevent the social panic and to increase reliability by communication activities, public declarations and statements. In this context, the Minister of Health regularly shared data such as daily tests, cases, deaths, and the number of patients recovering, both in live broadcasts, on social media accounts and on the website of the Ministry of Health. The Minister of the Interior regularly announced the measures and prohibitions. The President made general evaluations every week and informed the public about the course of current measures and incoming measures and restrictions.

The Minister of Economy made statements regarding the measures taken and the support packages implemented in the field of economy. Each ministry making statements related to their domains and areas of expertise contributed to the effort to inform the public with healthy and valid information and prevented ambiguity. In 
addition, advisory decisions made by the Scientific Board were highlighted in the statements of each official and thus, it was stated that the measures to be implemented were taken under the leadership of the Scientific Board and within the framework of science. In this way, the government tried to minimize actions such as violating or not obeying the decisions taken.

Explanations and policies implemented within the scope of social consensus are based on unity and solidarity. In this context, the campaign, initiated by the President himself and the active use of Twitter hashtag "\#evdekal" ("stay at home" in Turkish) aimed to create public awareness and to prevent the atmosphere of fear created by the pandemic. The messages given had mainly integrative content. The initiatives of state officials and political parties also found a response in the society and numerous needs of citizens over 65 years, such as shopping and medicinal procurements were met by their neighbors, who organized mainly on social media on the basis of volunteering. In addition to this voluntary organization, which is an important social assistance campaign, the municipalities also organized voluntary teams to provide citizens with the goods and equipment they need. Several local municipalities handed out prepacked food crates by visiting people in need.

"\#evdekal" hashtag was supported by opinion leaders and celebrities on social media and the severity of the Covid-19 pandemic has been made visible by sharing videos and visuals on social media in this direction. It is possible to see these efforts as organized initiatives to reinforce the social awareness towards the pandemic.

\subsection{Crisis Communication, the Covid-19 and the importance of information management}

The century we live in might be considered as a period in which many things become technical, in which time becomes important but the elements in the social or economic system are not always in harmony with each other. Conflicts between the subsystems that make up our ecosystem create extraordinary environments and situations, which are called crises. According to Turkish Language Association (TDK), the meaning of the crisis is defined as "the difficult period, crisis, depression seen in a country or between countries, in the life of a society or an organization" (Turkish Language Association, no date). It is stated that, in order to define a situation as a crisis, the following three conditions are required:

- The reputation of the institution or organization is damaged and this damage threatens its goals,

- $\quad$ The time required to solve the problem is very limited,

- $\quad$ The event occurs in an unexpected time by the institution or organization (Winner, 1990).

In order to turn crisis into opportunities or manage them correctly, the communication activities constitute the most important element for the leader or organization that has experienced the crisis. It is possible to prevent possible negative effects by minimizing the damage utilizing appropriate public relations practices and communication strategies. Therefore, public relations and communication have an important place in times of crisis. Institutions and organizations implement their public relations activities in any given time and thus, public relations stand out as a tool for effective communication for them. However, public relations activities become more meaningful and important in times of crisis. Especially the 1929 Great Depression period increased the importance of public relations (Kazanc1, 2019). Thus, the importance of public relations is better understood in order to get out of crisis environments with the least harm or to turn the crisis into an opportunity.

As one of the most important factors in crisis management, delegation of authority is emphasized. A special team that will be established at times of crisis to study the issue that causes the crisis should be responsible for planning and managing and implementing all activities to protect the society, institutions and organizations from the impact of the crisis (Budak \& Budak, 1995). The communicational activities with the public should be carried out by the board and the chairman of the crisis before the crisis starts, when the symptoms of the crisis begin to appear and after the crisis. Kazanc1 (2019) suggests not to let anyone and everyone talk and make statements about the crisis and asserts that sharing correct and reliable information with the media is very important in crisis management.

Contrary to normal times, communication planning during a crisis is of significant importance. 'Who will be responsible for informing the relationship with the media and the public?', 'what information will be disclosed?' and 'what are the rules that must absolutely be in media planning?' are some of the critical questions of this process. The need to talk about who to contact, how to address the audience, and what to talk about and what not to give too much detail about should be in communication planning (Luecke, 2008). Especially in crisis situations involving not only the media, but the whole society, all social layers should be considered as a stakeholder in effective crisis management. In crisis situations, judgment and criticism of responsible managers are frequently 
encountered. The important thing here is that the crisis reveals a panic atmosphere and it is natural for people to overreact in a fearful temper. For this reason, people in managerial positions should avoid explanations, attitudes and behaviors that will deepen the crisis. Therefore, it would be a correct approach to get rid of the negative facts, to overcome the shock effect and accept the results. As Birnbaum (2002) stated, the strategy of "tell everything, tell me immediately, tell yourself" may be appropriate.

Leadership is of special importance in times of crisis. Leaders are responsible for leading the team that will be established during the crisis. In this context, they undertake the task of achieving the common goal, keeping the team established together and motivating (Adair, 2013). Another role of leaders is to take on the role of minimizing the damage that will emerge during and after the crisis. In addition, they might have important roles in shortening the duration of the crisis since leaders are naturally figures of authority in crisis environments. Leaders should ensure that they are flexible as well as being determined during the crisis. The importance of the crisis fighting team they set up is another important point in the leadership of the crisis moment (Kowalski, Mallet, \& Brnich, 1996).

In times of crisis, the authorities need to empathize when communicating with the community, and they must state that they understand how they feel. Especially communicating in times of crisis is of special importance for creating social awareness and developing behavior towards the crisis. When it comes to the times of global crisis, the importance of communicating becomes more important in order to develop social belonging and to adopt the understanding of "us" instead of "I" (Lunn, et al., 2020). In the Covid-19 pandemic, the importance of communication was once again understood and effective communication was established, and social awareness was created and a social struggle against pandemics was ensured.

The use of social media as a communication method, which is one of the numerous opportunities that new media technologies involve, has also become widespread. However, social media also causes false or irrelevant information to spread uncontrollably (Bovet \& Makse, 2019). Several studies carried out on social media sharing about the Covid-19 draw attention to the numerical magnitudes and negative impacts of sharing based on fake information and the dangerous situations they cause:

"Based on a machine learning analysis of 112 million public social media posts, in 64 languages, related to the Covid-19 pandemic, researchers at the Bruno Kessler Foundation found $40 \%$ of posts came from unreliable sources. Another study using machine learning techniques, by the Foundation's the Covid-19 Infodemic Observatory, found that almost $42 \%$ of over 178 million tweets related to the Covid- 19 were produced by bots, and $40 \%$ were "unreliable". Approximately 19 million out of nearly 50 million (38\%) tweets related to the Covid-19 analyzed using artificial intelligence by Blackbird.AI were deemed to be "manipulated content. Newsguard identified 191 websites in Europe and North America that have published false information about the virus" (UNESCO, 2020).

According to the researches conducted during the Zika and Ebola virus outbreaks, the opinion that the use of social media by experts in the field does not contribute to increasing the quality of the knowledge and disseminating information (Abramson \& Piltch-Loeb, 2016) is emphasized. Moreover, some researches suggest that use of social media radiates panic and obscurity (Kilgo, Yoo \& Johnson, 2018). During the MERS outbreak in 2015, it was feared that fear and panic would spread through social media, but with the measures taken, social media use evolved in a positive way (Oh, Lee, \& Han, 2020). Therefore, supportive side tools should be used when using social media in crisis communication. A potential spread of misinformation can cause fear, panic, and distrust towards authority. In addition, unfounded, exaggerated or unrealistic information, especially on social media, overshadows healthy and accurate information emitted by authoritative sources, thereby weakening states' combat power in the event of a serious crisis such as a pandemic. Both the Zika and Ebola pandemics and the MERS pandemic set an example in this context. Therefore, it seems possible to state that the use of social media should be monitored and managed carefully for the Covid-19 crisis / pandemic in order to prevent panic and fear among people.

\section{Main communicational perspectives shaping the Covid-19 perception of Turkish society}

In this study, which focuses on the people's ways of obtaining information through the media and the general perception towards the Covid-19 in the outbreak process, the perception of the society about the Covid-19 process is discussed in the light of three basic perspectives of communication. These three perspectives, which are briefly described below, define the processes that stand out as the three basic categories that shape the communicational 
activities of both the society and the government through the media and determine their perceptions and attitudes towards the pandemic.

\subsection{General perception of society about the Covid-19}

The general perceptions of the society about the Covid-19 outbreak provides information about how the outbreak is perceived as a threat to both everyday life of all citizens and also a serious danger with potential threats that can cause severe health problems as well as death.

\subsection{Main sources of information about the pandemic and authorization of experts as main spokespersons}

This perspective focuses on questions such as 'what sources of information the society refers to in their search for information about the pandemic in Turkey?', 'What are the most reliable sources of information?' and 'to what extent individuals consider information on social media about the pandemic as reliable?'. It is stated that one of the difficulties that official authorities might face is the 'information gap' (Zang et al., 2020) and the society's growing need to fill this gap. Therefore, it would be a meaningful effort to investigate the information sources individuals use in an attempt to fill this information gap, especially in early periods, when the first cases were started to be diagnosed in Turkey.

The importance of leadership during the crisis was discussed in previous sections. In the Covid-19 process in Turkey, the most significant role in the struggle against the pandemic is mostly undertaken by the Scientific Board. In other words, the Scientific Board consisting of scientists in the field has assumed the main leadership position in the fight against the Covid-19 outbreak. The Board, as the main decision-making mechanism, enabled the government to build an integrated management process, and to avoid conflicting expert comments. The contradictory statements of the experts can cause negative effects on the fight against the outbreak. For example, it is emphasized that the conflicting opinions of different experts in the field that the mortality rates may change according to the testing policy may lead to the emergence of question marks on the accuracy of the data, which may cause negative effects in the fight against the pandemic (Pisano, Sadun and Zanini, 2020). Scientific Board has undertaken the basic source of information as the main decision-making structure in the Covid-19 crisis in Turkey, which resulted in settling itself as the most important actor and leader of the fight against the pandemic in Turkey.

\subsection{Social solidarity perception and overview of campaigns}

Although organized differently in many countries, it is possible to come across social solidarity and aid campaigns with similar emphasis in the Covid-19 process. These aid campaigns can basically be considered as social campaigns aimed at mobilizing large masses in topics such as obeying to the measures taken and helping people in need, by emphasizing social solidarity in the fight against pandemic. In this context, these campaigns symbolize the important initiatives in which the communication activities of the countries are intensified during the fight against the Covid-19.

\section{Method}

\subsection{Survey Information}

The method of gathering data from the field is a survey study, conducted under the directives of Republic of Turkey Ministry of Interior. Ministry of Interior has a mission of "building a disaster resilient society" (Ministry of Interior, n.d.). In addition, Internal Security Strategies Department of Ministry of Interior has a job description as follows: "doing or having done the necessary research, analysis and evaluation studies regarding internal security, informing the public and communicating with the public" (Ministry of Interior Dept. of Internal Security Strategies, n.d.). Three surveys were conducted in accordance with these mission statements in order to reveal the general perceptions of Turkish people towards the Covid-19 outbreak between April 1-3 (First Survey), April 7-9 (Second Survey) and April 13-15 (Final Survey). The surveys were conducted using Computer Aided Web Interviewing (CAWI) technique. In the CAWI technique participants fill out the questionnaire on the computer, mobile phone and tablets etc. and there is no need for an interviewer. The main reason for doing the survey by using CAWI technique was the restrictive pandemic conditions. During the pandemic, face-to-face interactions were prohibited by the government to prevent the spread of the virus. Therefore, an advertisement link was published on social media platforms in a way that citizens living in 26 provinces can see and they were expected to answer the question form via the advertisement link. For each survey, only the participants selected from social media who completed the questionnaire completely were included in the research. Conducting three sequential surveys made it possible week by week comparison of the changes in general perceptions of people. 
The main objectives of the surveys are described below.

- Understanding the perceptions of Turkish citizens about the Covid-19 pandemic,

- $\quad$ Measuring the extent of Turkish people's concerns about the Covid-19 when it first appeared in China and their concerns upon the occurrence of the first case in Turkey,

- To determine Turkish people's opinion on the measures taken by the state,

- Identifying the government's thoughts on its performance against the Covid-19

- To understand whether people find it necessary to impose a total curfew across the country,

- To learn Turkish people's thoughts about solidarity campaign and social support groups,

- To understand which of the news sources they use during the process trust most.

In this context, each of the three surveys was conducted in 26 provinces with participants over 18 years old and the participant numbers from each province were determined according to the populations of each province. 26 provinces were selected in accordance with the classifications of the European Union that suggests cities to be divided into three levels. The purpose of this three-level segmentation of cities is defined as determining the regional policy framework, conducting a socio-economic analysis of regions, and producing regional statistical data comparable at the European level. While creating the three-tier regional system for the survey, 81 provinces were defined as Level 3. Neighboring provinces, which are similar in economic, social, and geographic terms, have been determined as Level 2 (26 provinces) and Level 1 (12 provinces) regions, taking into account the regional development plans and population sizes. For this reason, according to level 2, 26 Level 2 provinces were chosen for the surveys.

The number of total participants for three surveys was 6021 (S1: 2006, S2: 2008, S3: 2007). 49.9\% of the participants were female, and 50.1\% were male (Table 1). Martial and educational status and other demographic status are shown in tables below (Table 2, 3 and 4).

Table 1. Gender properties of the participants of three surveys

\begin{tabular}{lccc}
\hline Gender & Survey 1 & Survey 2 & Survey 3 \\
\hline Female & $50.0 \%$ & $49.7 \%$ & $50.0 \%$ \\
\hline Male & $50.0 \%$ & $50.3 \%$ & $50.0 \%$ \\
\hline
\end{tabular}

Table 2. Marital status of the participants of three surveys

\begin{tabular}{lccc}
\hline Marital Status & Survey 1 & Survey 2 & Survey 3 \\
\hline Married & $45,0 \%$ & $43,9 \%$ & 45,7 \\
\hline Single & $46,9 \%$ & $46,7 \%$ & $45,3 \%$ \\
\hline Widow/Divorced & $8,1 \%$ & $9,4 \%$ & $8,9 \%$ \\
\hline
\end{tabular}

Table 3. Educational status of the participants of three surveys

\begin{tabular}{llll}
\hline Education Status & Survey 1 & Survey 2 & Survey 3 \\
\hline University & $27.2 \%$ & $27.4 \%$ & $26.7 \%$ \\
\hline High School & $54.9 \%$ & $55.7 \%$ & $56.5 \%$ \\
\hline Primary School & $17.2 \%$ & $16.1 \%$ & $16.0 \%$ \\
\hline No Diploma & $0.7 \%$ & $0.7 \%$ & $0.8 \%$ \\
\hline
\end{tabular}

Table 4. Demographic data of the participants of three surveys

\begin{tabular}{lccc}
\hline Age Group & Survey 1 & Survey 2 & Survey 3 \\
\hline $18-24$ & $15.6 \%$ & $15.5 \%$ & $15.2 \%$ \\
\hline $25-34$ & $21.3 \%$ & $21.1 \%$ & $21.4 \%$ \\
\hline $35-44$ & $21.1 \%$ & $20.8 \%$ & $20.7 \%$ \\
\hline $45-54$ & $17.5 \%$ & $17.0 \%$ & $17.4 \%$ \\
\hline $55-64$ & $14.2 \%$ & $13.3 \%$ & $12.4 \%$ \\
\hline Over 65 & $10.3 \%$ & $12.5 \%$ & $12.6 \%$ \\
\hline
\end{tabular}

In all three surveys, same questions were repeated except some additional questions were added to S3. These additional questions were added to include measures and restrictions that were not existent when previous two 
surveys were conducted (for instance, curfew for citizens under the age of 20, fines for those who do not comply with the rules, free mask distribution to citizens and ban on the whole weekends). Therefore, data on these questions are not available for S1 and S2. The data was analyzed in SPSS.

This research has ethics committee approval from Ankara Haci Bayram Veli University with 24.03.2021 date and E-11054618-302.08.01-16557 number.

\section{Analyses}

\subsection{The general perception of society about the Covid-19}

One of the most serious consequences in the very first days of the pandemic has been the death rate. While statistics on those who lost their lives due to the Covid-19 were shared only by China in the beginning, which was the epicenter of the pandemic, the number of deaths after the virus spread to other countries started to become evident. The rates of death, which are revealed by graphs and daily shared data, can be seen as an important factor shaping the public's general perception of the Covid-19 outbreak.

After the first the Covid-19 case in Turkey was announced on March 10, 2020 the public attention and awareness towards the outbreak increased (Trthaber, 2020b). The daily reports narrated by the Minister of Health in television broadcasts reached a record number of audiences (Nethaber, 2020). An important indicator of the threat caused by the pandemic is the awareness of the number of people who lost their lives worldwide due to the outbreak (Table 5). It is noteworthy that the awareness of the participants about the total number of people who died due to the pandemic worldwide was relatively low. In addition, it is seen that the awareness in question decreased from $34.9 \%$ in the first survey to $26.9 \%$ in the third survey. This lower rate might be explained by the difficulty of keeping daily updated numbers in mind. On the other hand, this might also be interpreted as participants of this study didn't pay sufficient attention in April to the total numbers of people who lost their lives due to the Covid19 in worldwide.

Table 5. Do you know how many people lost their lives in worldwide since the outbreak started? (\%)

\begin{tabular}{lccc}
\hline & $1-3$ April 2020 & $7-9$ April 2020 & $13-15$ April 2020 \\
\hline No & $65.1 \%$ & $74.6 \%$ & $73.1 \%$ \\
\hline Yes & $34.9 \%$ & $25.4 \%$ & $26.9 \%$ \\
\hline
\end{tabular}

When it comes to the awareness of participants about the total number of people who died because of the outbreak in Turkey, the rates are relatively higher (Table 6). While the average awareness rate for worldwide data is only $26.09 \%$, the average for the three surveys of the same data for Turkey is $47.13 \%$. This situation can be evaluated as an indicator that the awareness increased when the most serious consequence of the Covid-19, the number of total deaths started to occur inside national borders. In other words, participants are more aware of how many people died in their own country than in foreign countries.

Table 6. Do you know how many people lost their lives in Turkey since the outbreak has emerged? (\%)

\begin{tabular}{lccc}
\hline & $1-3$ April 2020 & $7-9$ April 2020 & $13-15$ April 2020 \\
\hline No & $42.1 \%$ & $57.5 \%$ & $59.0 \%$ \\
\hline Yes & $57.9 \%$ & $42.5 \%$ & $41.0 \%$ \\
\hline
\end{tabular}

Since the first day of the Covid-19 outbreak, all communities on a global scale have focused on the issue. However, the perception of the pandemic as a 'threat' seems to have happened to a large extent after the first cases began to appear in each country. A recent study revealed significant positive correlations between the fear of the Covid-19, depression, anxiety, and stress (Satici et al., 2020). It is observed that geographical proximity is an important factor shaping social perceptions in the early stages of the pandemic threat. Survey results show that while the levels of seeing the outbreak as a serious threat and feeling fear and anxiety because of the outbreak, in the period when it first emerged in China is relatively low (Table 7), the same rates are remarkably higher in the period when the outbreak reached Turkey (Table 8). While the rate of participants who state that they were 'ScaredVery Scared' when the Covid-19 outbreak emerged in China was \%21 in S3, it is observed that the same rate went as high as $\% 79.1$ when the outbreak reached Turkey. This dramatic change might be explained with the proximity factor. When the outbreak, with its deathly consequences emerges in the country, people feel way more scared of it. Same rate also seems to be increasing with time. Although all of the three surveys were carried out in the first 15 days of April, the increase in the rate of those who feel 'Scared-Very Scared' from S1 to S3 is remarkable (S1: $\% 77.8, \mathrm{~S} 3: \% 79.1)$. 
Table 7. To what extent were you scared when the outbreak emerged in China?

\begin{tabular}{llll}
\hline & $1-3$ April 2020 & $7-9$ April 2020 & $13-15$ April 2020 \\
\hline Not Scared at All - Not Scared & $61.4 \%$ & $69.0 \%$ & $65.8 \%$ \\
\hline Moderately Scared & $15.1 \%$ & $13.2 \%$ & $13.2 \%$ \\
\hline Scared - Very Scared & $23.4 \%$ & $17.8 \%$ & $21.0 \%$ \\
\hline
\end{tabular}

Table 8. To what extent were you scared when the outbreak reached Turkey?

\begin{tabular}{llll}
\hline & $1-3$ April 2020 & $7-9$ April 2020 & $13-15$ April 2020 \\
\hline Not Scared at All - Not Scared & $9.8 \%$ & $8.0 \%$ & $9.2 \%$ \\
\hline Moderately Scared & $12.5 \%$ & $14.1 \%$ & $11.7 \%$ \\
\hline Scared - Very Scared & $77.8 \%$ & $77.9 \%$ & $79.1 \%$ \\
\hline
\end{tabular}

In the case of a pandemic, one of the most important fears of the society is the health system and whether hospitals can handle the burden or not. After the transformation of health care system in recent years, Turkey has shown increasing signs of development in terms of both covering the majority of the population through social security system for financing of health care services and technical and accommodational capacities of hospitals in public and private sector (Tatar et al, 2011). It is seen in Table 9 and Table 10 that the trust of the society in the health system continues during the pandemic and that people believed that the health system will overcome the pandemic. In this context, even in periods when the Covid-19 outbreak reached near the peak rates in terms of daily cases and death rates, it was observed that the trust in the health system increased from S: 1 to $S: 3$. In addition, according to the results displayed in Table 10, the rate of participants who think that the Turkish health care system performed better than EU countries is noteworthy.

Table 9. Do you think our health system is strong enough to overcome the outbreak?

\begin{tabular}{lccc}
\hline & $1-3$ April 2020 & $7-9$ April 2020 & $13-15$ April 2020 \\
\hline Yes & $40.5 \%$ & $53.3 \%$ & $57.0 \%$ \\
\hline Partially & $42.5 \%$ & $38.5 \%$ & $35.3 \%$ \\
\hline No & $17.0 \%$ & $8.2 \%$ & $7.8 \%$ \\
\hline
\end{tabular}

Table 10. How effective do you find our country's health system in dealing with the Covid-19 cases when compared to those in European countries? (\%)

\begin{tabular}{lccc}
\hline & $1-3$ April 2020 & $7-9$ April 2020 & $13-15$ April 2020 \\
\hline Worse & $23.3 \%$ & $24,00 \%$ & $28.67 \%$ \\
\hline Same & $24.1 \%$ & $17.1 \%$ & $15.2 \%$ \\
\hline Better & $52.6 \%$ & $58.9 \%$ & $56.2 \%$ \\
\hline
\end{tabular}

Among the measures taken by Turkish government for slowing down the rate of infection, the most remarkable ones were the curfews and cancellation of all events and organizations such as sports events and concerts (Karadağ and Gemici, 2020; Hamit and Güler, 2020). According to the findings (Table 11), it is possible to state that participants reacted positively to the most compelling measures. Postponing events and curfew for people over the age of 65 were among the most positively perceived measures in all three surveys (Postponing events S1:4.5, S2:4.5, $\mathrm{S} 3: 4.6$; Curfew over $65 \mathrm{~S} 1: 4.5, \mathrm{~S} 2: 4.4, \mathrm{~S} 3: 4.6)$.

Table 11. How positive do you think the measures taken by the government about the Covid-19 were? *

\begin{tabular}{lccc}
\hline & $1-3$ April 2020 & 7-9 April 2020 & 13-15 April 2020 \\
\hline Postponing sports events & 4.54 & 4.51 & 4.63 \\
\hline Curfew imposed on people over 65 & 4.45 & 4.44 & 4.60 \\
\hline Prohibition of mass worship & 4.46 & 4.36 & 4.48 \\
\hline Curfew imposed on people under 20 & & 4.35 & 4.46 \\
\hline Imposing fines on people not complying with the measures & & 4.31 & 4.45 \\
\hline Distributing free masks to citizens & 4.35 & 4.40 & 4.45 \\
\hline Punishment for those who spread false news on social media & 4.42 & 4.28 & 4.44 \\
\hline Online banking \& financial services & 4.11 & 4.30 & 4.42 \\
\hline Switching to work from home & 3.81 & 4.25 & 4.37 \\
\hline Curfews imposed on weekends & 4.13 & 4.16 & 4.24 \\
\hline Switching to online education system & 4.11 & \\
\hline Providing many health services online & & \\
\hline
\end{tabular}




\subsection{Main sources of information about the pandemic and authorization of experts as main spokespersons}

In cases such as pandemic, reliable and transparent information sharing both protects the society from panic and increases confidence in the government (Khosravi, 2020). In this context, the trust of the Turkish public in the information shared by the authorized bodies (Table 12) during the pandemic was $79.5 \%$, in S: 1 and partially increased to $87.8 \%$ in S: 2 , and the same rate was $86.3 \%$ in S: 3. Similarly, the rate of the participants who state that they trust the statements of the authorized bodies increased from $39.2 \%$ in $\mathrm{S}: 1$ to $45.9 \%$ in $\mathrm{S}: 2$, and the same rate increased to $51.1 \%$ in S: 3 . In addition, while the rate of those who stated that they did not trust the statements of the authorized bodies was $20.5 \%$ in S: 1 , this rate dropped dramatically to $12.7 \%$ in $\mathrm{S}: 2$ and was $13.7 \%$ in $\mathrm{S}$ : 3. Therefore, it can be stated that, in the light of the results of the study sample, Turkish society trusts official explanations about the Covid-19 pandemic.

Table 12. Do you agree that state officials were transparent in sharing information about the outbreak? (\%)

\begin{tabular}{lccc}
\hline & $1-3$ April 2020 & $7-9$ April 2020 & $13-15$ April 2020 \\
\hline Yes & $39.2 \%$ & $45.9 \%$ & $51.1 \%$ \\
\hline Partially & $40.3 \%$ & $41.9 \%$ & $35.2 \%$ \\
\hline No & $20.5 \%$ & $12.2 \%$ & $13.7 \%$ \\
\hline
\end{tabular}

From the emergence of the first cases of the outbreak in Turkey, it seems that participants of the study consider state officials and the members of Scientific Board as reliable sources of information (Table 13). According to the results in S: 1, it can be seen that participants pay attention mostly to the statements of the government most, the statements of the members of the Scientific Committee are in the second place and it is seen that other discussions on the television channels and the statements on social media are not taken seriously. In S: 2 , while the statements of the government are in the first place as the most trusted statements, an increase in the statements of the members of the Scientific Board has been observed and the confidence in the discussions on television programs and social media has decreased. In S: 3 , the statements of the Scientific Board rose to the first place with $47.9 \%$, and the statements of the government fell to the second place with $43.9 \%$, as well as the statements on television channels and the statements made on social media decreased sharply compared to S 1 . In this context, it can be stated that the Turkish public sees Science Board members and official bodies as reliable sources of information. In this way, it is among other findings that information pollution caused by the explanations made on television channels and social media is prevented. It is also among the other findings that, between S: 1 and S: 3, the trust in the Scientific Committee's explanations increased and the Turkish society found the scientific explanations more reliable.

Table 13. In your opinion, from which sources the most reliable information about the Covid-19 can be obtained? $(\%)$

\begin{tabular}{lccc}
\hline & $1-3$ April 2020 & $7-9$ April 2020 & 13-15 April 2020 \\
\hline Firsthand Reports from Government Officials & $49.2 \%$ & $45.8 \%$ & $43.9 \%$ \\
\hline Statements of Science Council & $38 . \%$ & $43.5 \%$ & $47.9 \%$ \\
\hline Statements from Discussion on TV Broadcasts & $8.4 \%$ & $6.9 \%$ & $5.4 \%$ \\
\hline Information on Social Media & $4.5 \%$ & $3.9 \%$ & $2.7 \%$ \\
\hline
\end{tabular}

\subsection{Social solidarity perception and overview of campaigns}

Economy can be considered as one of the areas that received the most damage from the Covid-19 outbreak. The damage is so severe that many researchers believe that the recovery of economic status of countries would take years (Allen and Mirsaeidi, 2020) and the damage might lead to a deeper economic crisis in global scale with impacts such as drops in production rates and collapses in delivery lines (Mckee and Stuckler, 2020). In this context, many countries have taken various measures according to their economic size and have taken loans from international funds such as IMF. Turkey launched a solidarity campaign in order to minimize the economic impact of the pandemic by encouraging citizens to donate for those who need currency. The official website https://bizbizeyeteriz.gov.tr/ enlisted the top-ranking donators on its website and the total amount of donations reached just over 2 billion Turkish Liras on June 24, 2020. However, the survey results show that (Table 14) the donation campaign in question was not welcomed by a considerable percentage of the participants. While those who have a negative perception of the campaign was $47.7 \%$ in $\mathrm{S}: 1$, negative and positive perceptions were equalized with $42.8 \%$ in S: 2 . However, in S: 3, negative perception stands out again with $46.2 \%$. Accordingly, it is possible to state that nearly half of the participants had negative perceptions towards the donation campaign launched by the state in order to minimize negative economic impacts of the Covid-19 outbreak. 
Table 14. What do you think about the national solidarity campaign launched by the President? (\%)

\begin{tabular}{lccc}
\hline & $1-3$ April 2020 & $7-9$ April 2020 & $13-15$ April 2020 \\
\hline Negative & $47.7 \%$ & $42.8 \%$ & $46.2 \%$ \\
\hline Neutral & $17 . \%$ & $14.4 \%$ & $15.1 \%$ \\
\hline Positive & $35.3 \%$ & $42.8 \%$ & $38.7 \%$ \\
\hline
\end{tabular}

\section{Discussion and conclusions}

The communication strategies of governments and the general perception of the society against the pandemic are two important components in combating the Covid-19 outbreak, which has emerged as an important crisis worldwide. It is evident in almost every society that large masses seek information to close the 'information gap' that suddenly arises against the emerging threat, and that many states try to answer this information need by providing healthy and accurate data. In this context, this study is an attempt to provide a general portrait of the Covid-19 process in Turkey by focusing on the general views of individuals on the outbreak as a threat and on the main strategies and communicational activities of the government.

Although social media and internet platforms are seen as useful and main means of reaching information for the society, in Turkey's case during the Covid-19 process, it is noteworthy that a vast number of participants of the field study defined official statements made by government officials as the most reliable sources of information. This situation has contributed significantly to the prevention of the harmful effects of false or exaggerated information and news spread over social media platforms, especially in the first days of the pandemic. It is also possible to state that, as it was discussed in detail in previous parts of the study, leadership played an important role in times of the Covid-19, which can also be defined as a serious crisis. Most of the participants turned their attention to the leading actors in their search for the accurate and right information. As media relations became an important factor affecting the information flow in the Covid-19 crisis, results indicate that leading actors used media efficiently since TV news was among the most popular news sources for daily official statements (Varan, 2020).

On the other hand, although some of the measures taken restricted the daily routine of social life significantly and created a heavy burden on society both economically and socially. The results of the field research indicate that the participants supported the measures taken to a certain extent. The acceptance and implementation of these measures, which play an important role in preventing new cases and therefore deaths are of great importance in combating the pandemic. The data suggest that an important number of participants regarded the measures and restrictions declared by the governing actors as acceptable and reasonable precautions.

Another important implication that might be derived from the results is that the national donation campaign, which was a prominent component of the communication strategy of the government, failed to get the expected attention. This might be viewed as the negative response of the participants towards a policy that actively positions every citizen as a responsible individual and asks for their contribution. As a feature of the social state, it's a widely believed view that the state should be responsible and undertake every need of the society in terms of health care and emergencies. In other words, the low level of the support of the participants for the donation campaign organized can be interpreted as an indication of the participants' expectations that all needs of the people in the Covid19 process should be met by the state without putting more weight on the shoulders of the citizens.

The Covid-19 process, which has rapidly emerged on a global scale and has become one of the most important items of the world agenda, undoubtedly becomes visible in different ways in each country. Nevertheless, the national experiences of the countries provide important clues both for revealing different perspectives of the societies in combating the pandemic regarding this crisis and for evaluating the managers' tactics and strategies to combat the pandemic in terms of success levels and the degree of public acceptance of the measures taken. This study, which may also be regarded as an evaluation in this perspective in the context of Turkey, can be viewed as an attempt to, evaluate the Covid-19 process in terms of communications, in the light of the data obtained from the field research in both perspectives. In this context, it can be an important contribution to develop different strategies and to plan effective communication activities globally. The experiences in different countries of the World would further enhance the level of contribution by providing a comparative perspective.

\section{Author contribution statements}

Z. Avşar, E. Ayaşlıoğlu, Ö.F. Zararsız and C.O. Tuncer contributed equally to the design and implementation of the research, to the analysis of the results and to the writing of the manuscript. 


\section{Disclosure statement}

No potential conflict of interest was reported by the authors.

\section{Ethics committee approval}

This research has ethics committee approval from Ankara Haci Bayram Veli University with 24.03.2021 date and E-11054618-302.08.01-16557 number. All responsibility belongs to the researchers. All parties were involved in the research of their own free will.

\section{References}

Abramson, D. and Piltch-Loeb, R. (2016). "U.S. Public's Perception of Zika Risk: Awareness, Knowledge, and Receptivity to Public Health Interventions. New York University, https://www.nyu.edu/content/dam/nyu/publicAffairs/documents/PDF/research/PiR2 Zika Report rf.pdf [Accessed: 27.03.2020].

Adair, J. (2013). Etkili Stratejik Liderlik. (F. Beşenek, Trans.) İstanbul: Babıali Kültür Yayıncılığı.

Allen, M. B. and Mirsaeidi, M. (2020). 'Health and Economy in the Covid-19 Era: A Plan for Reconstituting Long-Term Economic Security’. Frontiers in Public Health, 8, 235. DOI: 10.3389/fpubh.2020.00235.

Birnbaum, J. H. (2002). 'Clinton's Defender is Playing Defense'. Fortune, 96.

Bovet, A. and Makse, H. (2019). 'Influence of fake news in Twitter during the 2016 US presidential election'. Nature Communications, 1(10), 1-14. DOI: https://doi.org/10.1038/s41467-018-07761-2

Budak, G. and Budak, G. (1995). Halkla İlişkiler. İstanbul: Beta Yayınları.

CNN Turk. (2020). Ankara'da kritik koronavirüs toplantıs1 sona erdi. https://www.cnnturk.com/video/turkiye/son-dakika-ankarada-kritik-koronavirus-toplantisi-sona-erdi [Accessed: 26.03.2020].

Deutsche Welle. (2020). Çin'den Türkiye'ye uçuşlar ay sonuna kadar durduruldu. https://www.dw.com/tr/\%C3\%A7indent\%C3\%BCrkiyeye-u\%C3\%A7u\%C5\%9Flar-ay-sonuna-kadar-durduruldu/a-52243626 [Accessed: 26.03.2020].

Euronews. (2020). Sağlı Bakanı Koca: Türkiye'de ilk koronavirüs (Covid-19) vakası tespit edildi. https://tr.euronews.com/2020/03/10/sagl-k-bakan-koca-koronavirus-covid-19-salg-n-ile-ilgili-ac-klama-yap-yor [Accessed: 19.05.2020].

Haberturk. (2020). Koronavirüs riskine karşı durdurulan uçuşlar. https://www.haberturk.com/koronavirus-riskine-karsi-durdurulan-ucuslar-2623940 [Accessed: 26.03.2020].

Hamit, D. and Güler, S., (2020). Turkey will use all means to eliminate coronavirus. Anadolu Agency. URL: https://www.aa.com.tr/en/latest-on-coronavirus-outbreak/turkey-will-use-all-means-to-eliminate-coronavirus/1770969 [Accessed: 16.04.2020]

Hürriyet. (2020). 65 yaş üstüne sokağa çıkma yasağı! İçişleri Bakanlığı duyurdu. https://www.hurriyet.com.tr/gundem/sondakika-haberi-icisleri-bakanligi-duyurdu-65-yas-ustune-disari-cikma-sinirlandirildi-41474569 [Accessed: 26.03.2020].

Karadağ, K. (2020). Türkiye'nin koronavirüsle mücadelesinde son 24 saatte yaşananlar. https://www.aa.com.tr/tr/koronavirus/turkiyenin-koronavirusle-mucadelesinde-son-24-saatte-yasananlar/1791816 [Accessed: 26.03.2020].

Karadă̆, A. and Gemici, O. O. (2020). Turkey begins implementing new COVID-19 measures, Anadolu Agency. URL: https://www.aa.com.tr/en/latest-on-coronavirus-outbreak/turkey-begins-implementing-new-covid-19-measures-/1791878. [Accessed: 2.05.2020].

Kazancı, M. (2019). Kamuda ve Özel Kuruluşlarda Halkla İlişkiler (12 b.). Ankara: Turhan Kitabevi.

Khosravi, M. (2020). Perceived Risk of the Covid-19 Pandemic: The Role of Public Worry and Trust. Electronic Journal of General Medicine, 4(17). DOI: https://doi.org/10.29333/ejgm/7856

Kilgo, K.D., Yoo, J. and Johnson, T. (2018). Spreading Ebola Panic: Newspaper and Social Media Coverage of the 2014 Ebola Health Crisis. Health Communication, 1(7), 1-7. DOI: 10.1080/10410236.2018.1437524

Kowalski, K. M., Mallet, L. and Brnich, M. (1996). Leadership Characteristics in Escape from Three Underground Mine Fires. The International Emergency Management and Engineering Conference (s. 317-326). Montreal: The International Emergency Management.

Luecke, R. (2008). Kriz Yönetimi. (Ö. Sarıkaya, Trans.) İstanbul: Türkiye İş Bankası Kültür Yayınları.

Lunn, P., Ireland, D., Belton, C., Lavin, C., McGowan, F., Timmons, S. and Robertson, D. (2020). 'Using Behavioral Science to Help Fight the Coronavirus: A Rapid, Narrative Review'. Journal of Behavioral Public Administration, 1(3), 1-37. DOI: https://doi.org/10.30636/jbpa.31.147

McKee, M. and Stuckler, D. (2020). 'If the world fails to protect the economy, the Covid-19 will damage health not just now but also in the future'. Nature Medicine, 26(5), 640-642. DOI: 10.1038/s41591-020-0863-y.

Ministry of Health. (2020). Türkiye'deki Güncel Durum. https://covid19.saglik.gov.tr/ [Accessed: 25.06.2020].

Ministry of Interior. (n.d.). Mission. Republic of Turkey Ministry of Interior: http://mia.gov.tr/mission [Accessed: 12.09.2020]. 
Ministry of Interior. (2020a). 2 Gün Sokağa Çıkma Yasağı. https://www.icisleri.gov.tr/2-gun-sokaga-cikma-yasagi [Accessed: 26.03.2020].

Ministry of Interior. (2020b). 30 Büyükşehir ve Zonguldak İlinde 23-24-25-26 Nisan Tarihlerinde Uygulanacak Sokağa Çıkma Kisitlaması. https://www.icisleri.gov.tr/30-buyuksehir-ve-zonguldak-ilinde-23-24-25-26-nisan-tarihlerinde-uygulanacaksokaga-cikma-kisitlamasi [Accessed: 26.03.2020].

Ministry of Interior Dept. of Internal Security Strategies. (n.d.). Hakkımızda https://www.icisleri.gov.tr/icguvenlik/hakkimizda [Accesed: 12.09.2020].

Nethaber. (2020). Reyting verileri açıklandı! Bakan Koca rekor kırdı. https://www.nethaber.com/gundem/reyting-verileri-aciklandi-bakan-koca-rekor-kirdi-20045 [Accessed: 6.05.2020].

Ntv. (2020a). İçişleri Bakanlığı'ndan genelge: Güzellik salonu, berber ve kuaförler kapanıyor. https://www.ntv.com.tr/turkiye/icisler-bakanligindan-genelge-guzellik-salonu-berber-ve-kuaforler-kapaniyor,xjU0IisJXkGY9-D23thsog [Accessed: 26.03.2020].

Ntv. (2020b). İçişleri Bakanlı̆̆ı'ndan genelge: Güzellik salonu, berber ve kuaförler kapanıyor. https://www.ntv.com.tr/turkiye/icisler-bakanligindan-genelge-guzellik-salonu-berber-ve-kuaforler-kapaniyor,xjU0IisJXkGY9-D23thsog [Accessed: 26.03.2020].

Oh, S.-H., Lee, S. and Han, C. (2020). The Effects of Social Media Use on Preventive Behaviors during Infectious Disease Outbreaks: The Mediating Role of Self-relevant Emotions and Public Risk Perception. Health Communication. DOI: https://doi.org/10.1080/10410236.2020.1724639

Pisano, G.P., Sadun, R. and Zanini, M. (2020). 'Lessons from Italy's Response to Coronavirus', Harvard Business Review. URL: https://hbr.org/2020/03/lessons-from-italys-response-to-coronavirus. [Accessed: 27.03.2020].

Satıcı, B., Gocet-Tekin, E., Deniz, M. E. and Satıcı, S. A. (2020). Adaptation of the Fear of the Covid-19 Scale: Its association with psychological distress and life satisfaction in Turkey. International Journal of Mental Health and Addiction, 1.

Sözcü. (2020). Corona virüsü nedeniyle eğitime verilen ara 30 Nisan'a kadar uzatıldı. https://www.sozcu.com.tr/2020/gundem/son-dakika-saglik-bakani-koca-ve-milli-egitim-bakani-selcuktan-corona-aciklamasi [Accessed:26.03.2020].

Sputnik. (2020a). Umreden dönen 10 bin 330 kişi Ankara ve Konya'daki öğrenci yurtlarında karantinaya alındı. https://tr.sputniknews.com/turkiye/202003151041598178-umreden-donenler-ankara-ve-konyadaki-yurtlarda-karantinaya-alindi/ [Accessed: 26.03.2020].

Sputnik. (2020b). YÖK Başkanı: Üniversitelerde bahar döneminde yüz yüze eğitim yapılmayacak, YKS 25-26 Temmuz'a ertelendi. https://tr.sputniknews.com/turkiye/202003261041691008-yok-baskani-universitelerde-bahar-doneminde-yuzyuze-egitim-yapilmayacak-yks-ertelendi/ [Accessed: 26.03.2020].

Sputnik. (2020c). Erdoğan, 'Milli Dayanışma Kampanyası'nı duyurdu: 7 aylık maaşımı bağışlayarak açıyorum. https://tr.sputniknews.com/turkiye/202003301041721380-cumhurbaskani-erdogan-aciklama-yapiyor/ [Accessed: 26.03.2020].

T24. (2020). Diyanet'ten Koronavirüs genelgesi: Cuma günü ve kandil gecesi camiler kapalı tutulacak. https://t24.com.tr/haber/diyanet-ten-koronavirus-genelgesi-cuma-gunu-ve-kandil-gecesi-camiler-kapali-tutulacak,[Accessed: 26.04.2020].

Taşkıran, İ. (2020a). Çin'den gelen yolcular termal kameralarla kontrol edildi. https://www.aa.com.tr/tr/koronavirus/cindengelen-yolcular-termal-kameralarla-kontrol-edildi/1717528 [Accessed: 26.03.2020].

Taşkıran, İ. (2020b). Yurt dışından gelen tüm yolcular termal kameralarla kontrol edilmeye başlandı. https://www.aa.com.tr/tr/koronavirus/yurt-disindan-gelen-tum-yolcular-termal-kameralarla-kontrol-edilmeyebaslandi/1727460 [Accessed: 26.03.2020].

Tatar, M., Mollahaliloğlu, S., Şahin, B., Aydın, S., Maresso, A., and Hernández-Quevedo, C. (2011). Turkey: Health system review. Health Systems in Transition Vol. 13 No. 6.

Trthaber (2020a). Türkiye'de koronavirüs kaynaklı ilk ölüm. https://www.trthaber.com/haber/gundem/turkiyede-koronaviruskaynakli-ilk-olum-467942.html [Accessed: 19.05.2020].

Trthaber (2020b). COVID-19 sürecinde sosyal medya platformları atağa kalktı. https://www.trthaber.com/haber/bilimteknoloji/Covid-19-surecinde-sosyal-medya-platformlari-ataga-kalkti-482157.html [Accessed: 8.05.2012].

Turkish Language Association. (No date). Kriz. https://sozluk.gov.tr/ [Accessed: 16.03.2020].

UNESCO, (2020). Journalism, press freedom and the Covid-19, United Nations Educational, Scientific and Cultural Organization. URL: https://en.unesco.org/sites/default/files/unesco_covid_brief_en.pdf. [Accessed: 18.03.2020].

Varan, G., (2020). Kovid-19 salgını televizyona ve haber kanallarına ilgiyi artırdı. Anadolu Agency. URL: https:/www.aa.com.tr/tr/koronavirus/kovid-19-salgini-televizyona-ve-haber-kanallarina-ilgiyi[Accessed: 22.11.2020].

Winner, P. (1990). Effective PR Management, A Guide to Corporate Success. London: Kogan Page Ltd.

Yener, D. (2020). Türkiye'nin koronavirüsle mücadele politikasına 'Bilim Kurulu' yön veriyor. https://web.archive.org/web/20200328180255/https:/www.aa.com.tr/tr/koronavirus/turkiyenin-koronavirusle-mucadele-politikasinabilim-kurulu-yon-veriyor/1777215 [Accessed: 26.03.2020].

Zhang, W., Wang, Y., Yang, L. and Wang, C. (2020). 'Suspending classes without stopping learning: China's education emergency management policy in the Covid-19 Outbreak'. J. Risk and Financial Management 13 (55). 